\title{
Noviemeter Diagnostic Test as a Head Circumference Measurement Device for Under-Five Children
}

\author{
Novita Ayu Indraswati, ${ }^{1}$ Ma'mun Sutisna, ${ }^{1}$ Achmad Suardi, ${ }^{1,2}$ Hidayat Wijayanegara, ${ }^{1,3}$ \\ Leri Septiani, ${ }^{1,4}$ Herry Garna ${ }^{1,5}$ \\ ${ }^{1}$ Applied Midwifery Master Study Program, STIKes Dharma Husada, Bandung, Indonesia, \\ ${ }^{2}$ Santosa Hospital Bandung Central, Bandung, Indonesia, ${ }^{3}$ Department of Obstetrics and Gynecology, \\ Faculty of Medicine, Universitas Islam Bandung, Bandung, Indonesia, ${ }^{4}$ RSIA Grha Bunda, Bandung, Indonesia, \\ ${ }^{5}$ Department of Child Health, Faculty of Medicine, Universitas Islam Bandung, Bandung, Indonesia
}

\begin{abstract}
The current typical practice for measuring the head circumference of under-five children is by using a measuring tape. However, it may create some difficulties as children cry and move during measurement, leading to less accurate results. Accurate head circumference measurement is essential for assessing brain development and early detection of brain development disorders. Therefore, a more accurate device to measure head circumference is needed. Noviemeter is a non-touch digitalized head circumference measuring device that enables easier measurement in under-five children. As a new tool, noviemeter's accuracy, sensitivity, and specificity must be determined. This study aimed to analyze the difference in the head of under-five children circumference measurement results between a typical measuring tape as the gold standard and noviemeter and determine the accuracy, sensitivity, and specificity of the noviemeter. It was a cross-sectional analytical study using cluster random sampling on 72 under-five children in the work area of Guntung Payung Public Health, South Kalimantan, during August 2020. The measurement was performed twice, first using a measuring tape and, second, using a noviemeter. Data were analyzed statistically using the dependent $t$ test and diagnostic test. No significant difference was found between the results of the two measuring devices $(\mathrm{p}=0.257)$. The sensitivity, specificity, and accuracy of the noviemeter were $87.0 \%, 88.4 \%$, and $91.8 \%$, respectively. Thus, noviemeter has good sensitivity, specificity, and accuracy as an easier alternative device to measure head circumference in under-five children.
\end{abstract}

Keywords: Diagnostic test, head circumference, measuring tape, noviemeter

\section{Uji Diagnostik Noviemeter sebagai Alat Pengukur Lingkar Kepala Balita}

\begin{abstract}
Abstrak
Praktik pengukuran lingkar kepala balita yang umum dilakukan saat ini adalah dengan menggunakan pita ukur. Akan tetapi, hal itu dapat menimbulkan beberapa kesulitan karena anak menangis dan bergerak selama pengukuran yang menyebabkan hasil yang kurang akurat. Pengukuran lingkar kepala yang akurat sangat penting untuk menilai perkembangan otak dan deteksi dini gangguan perkembangan otak. Oleh karena itu, diperlukan alat yang lebih akurat untuk mengukur lingkar kepala. Noviemeter merupakan alat pengukur lingkar kepala digital nonsentuh yang memungkinkan pengukuran lebih mudah pada anak balita. Sebagai alat baru, akurasi, sensitivitas, dan spesifisitas noviemeter harus ditentukan. Penelitian ini bertujuan menganalisis perbedaan hasil pengukuran lingkar kepala balita antara pita ukur tipikal sebagai baku emas dan noviemeter serta mengetahui akurasi, sensitivitas, dan spesifisitas dari noviemeter tersebut. Jenis penelitian ini adalah cross-sectional analytical dengan menggunakan cluster random sampling pada 72 balita di wilayah kerja Puskesmas Guntung Payung Kalimantan Selatan selama bulan Agustus 2020. Pengukuran dilakukan dua kali, pertama menggunakan pita pengukur dan kedua menggunakan noviemeter. Data dianalisis secara statistik menggunakan uji t dependen dan uji diagnostik. Tidak ditemukan perbedaan yang signifikan antara hasil kedua alat ukur $(p=0,257)$. Sensitivitas, spesifisitas, dan akurasi noviemeter masing-masing adalah 87,0\%; 88,4\%; dan 91,8\%. Dengan demikian, noviemeter memiliki sensitivitas, spesifisitas, dan akurasi yang baik sebagai alat alternatif yang lebih mudah untuk mengukur lingkar kepala pada anak balita.
\end{abstract}

Kata kunci: Lingkar kepala, noviemeter, pita ukur, uji diagnostik

Received: 15 March 2021; Revised: 2 December 2021; Accepted: 7 December 2021; Published: 31 December 2021

Correspondence: Novita Ayu Indraswati. Applied Midwifery Master Study Program, STIKes Dharma Husada. Jln. Terusan Jakarta No. 71-75, Bandung 40282, West Java, Indonesia. E-mail: novitaayuindraswati@gmail.com 


\section{Introduction}

Under-five children's growth is among the critical factors for improving the quality of life of a nation's future generation. Although most parents understand the importance of brain development for their child's future, not many of them know that it is essential to measure their child's head circumference to estimate the inner volume of the head, which will reflect the growth of the brain. ${ }^{1-3}$

Under-five children with a head circumference disorder are at a higher risk of developing developmental disorders, nine times higher than those with normal head circumference. ${ }^{4}$ Monitoring the head circumference of infants is essential because it can detect abnormalities that will trigger further examinations of the head to identify the cause, leading to early interventions for the abnormality. With early interventions, the consequences of the brain growth abnormality, such as mental retardation and under-developed brain, can be lessened. When the circulation of the cerebrospinal fluid in the brain is disturbed, the head will be enlarged (macrocephaly), which is known as hydrocephaly or fluid accumulation in the brain, and brain growth and development will be impaired. ${ }^{5,6}$

The average size of a newborn's head, both boys and girls, is $33-35 \mathrm{~cm}$. Several sources stated that the skull's growth in under-five children follows the growth and development of the brain. Thus, when the skull growth is disturbed, brain development is hampered.7.8 In a study involving 633 children, it is suggested that the head circumference can be used as one of the benchmarks for a child's ability level. ${ }^{3}$ In addition, a study by Ribek et al. ${ }^{9}$ demonstrated a correlation between head circumference and brain growth and development in infants aged o-12 months.

Errors in the process of head circumference measurement will affect the results. These errors may come from the use of inappropriate tools for measurement. There are concerns regarding the weaknesses of the conventional measuring instrument typically used for measuring head circumference. These weaknesses include difficulty in seeing or reading the measuring lines, leading to rounding of $0.5^{-1.0} \mathrm{~cm}$ up or down; the need for good lighting during measurement; and impractical method of measuring. ${ }^{3,10-12}$

A digital tool for measuring health circum- ference will benefit health workers as it addresses some of the weaknesses mentioned above. Noviemeter is a solution designed by the authors to measure the under-five children's head circumference from the glabellar or supraorbital bone to the occipital bone in a digitized manner so that the result can be easily interpreted. It is expected that this tool will enable early detection of any abnormality in the child's head circumference. Noviemeter, as a head circumference measuring device, uses infrared proximity sensors that are safe for humans. This device is user-friendly and practical as the user only needs to put the holder above the head. The program will calculate the head circumference, and the results will appear on the monitor display. This tool is specifically designed as a non-touch device, meaning that it will not directly contact the child's head. The measurement results using this device can then be compared to the normal circumference according to the child's age and gender for further assessment. The limitation of this device is that it does not have a memory storage facility and graphical display.

The purpose of this study was to analyze the differences in the results of head circumference measurement between the conventional measuring tape and noviemeter. In addition, the accuracy (sensitivity and specificity) of noviemeter in measuring the head circumference of under-five children was also assessed.

\section{Methods}

It was a cross-sectional observational study using cluster random sampling. ${ }^{13,14}$ The cluster for this study was defined by residency area. Each subject had their head circumference measured twice. The first measurement was performed using a measuring tape, while the second used a noviemeter, and two different operators conducted both measurements. During the recruitment of the subject, 72 children aged 36-60 months who met the inclusion criterion were recruited. The inclusion criteria used were aged 36-6o months old, healthy, and parents or guardians were willing to consent their child to participate in this study. The instruments used to collect data were a questionnaire, a measuring tape, and a noviemeter. A bivariate statistical analysis using the dependent $t$ test and diagnostic test was performed on the data. ${ }^{15}$

Noviemeter uses four infrared proximity 


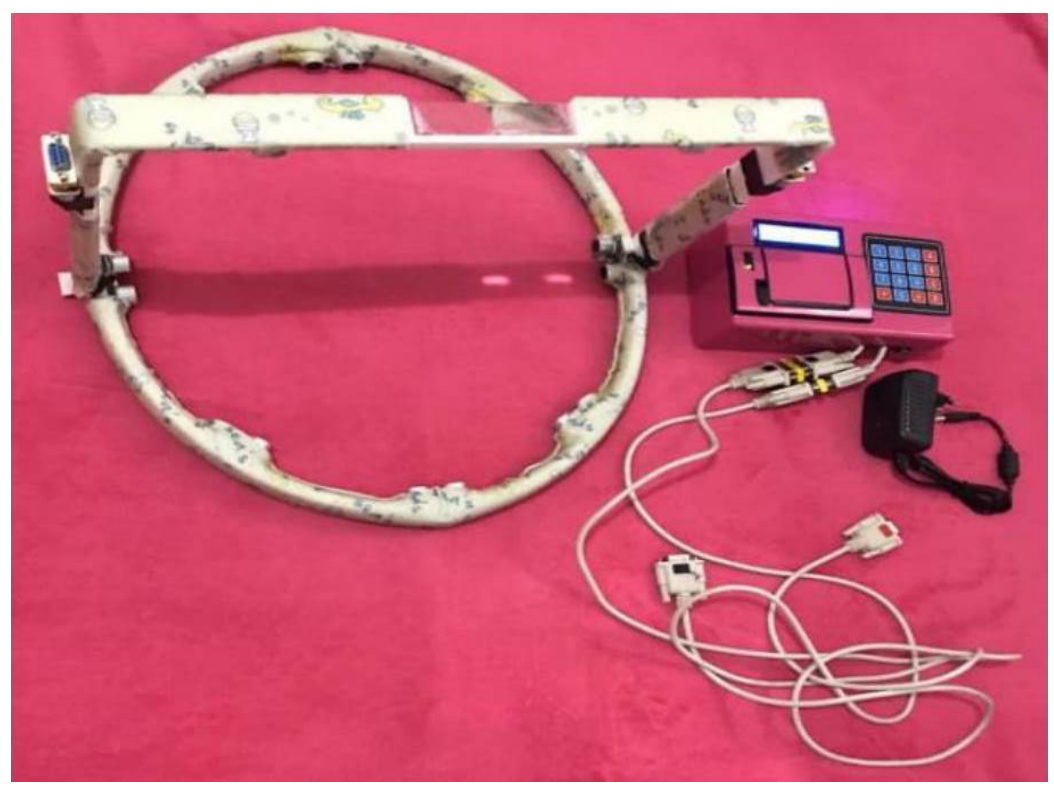

Figure Noviemeter

sensors that will convert the measurement results from distance to an electrical signal that will be read by a microcontroller, which in turn will process the signal into letters and numbers using an analog to digital converter (ADC). The result of this process is diameter measures (D1, D2, D3, and D4). A computerized program then calculates the head circumference by referring to the child's age and gender using a 2-dimensional ellipse formula. The result of the head circumference measurement is then sent to the LCD monitor. In the study, the operator typed in the gender and age of the child and then placed the holder above the child's head. The measurement results then appeared on the LCD after about 1-2 seconds, and the operator pressed the print button to get the printed output of the measurement. The research was obtained from the Health Research Ethics Committee of the STIKes Dharma Husada Bandung ethical approval number: o8/SDHB/B/ VIII/2020.

\section{Results}

Table 1 shows the majority of the subjects of this study were boys (56\%) aged 36-48 months old (61\%).

The result of the data normality testing on head circumference measurement using the Kolmogorov-Smirnov test in this study presented a p value of 0.093 , showing normally distributed data (Table 2). In addition, it made dependent $\mathrm{t}$ test analysis possible. The head circumference results using the two measurement results

Table 1 Subject Characteristics

\begin{tabular}{lc}
\hline Characteristics & $\mathbf{n = 7 2 ( \% )}$ \\
\hline Gender & \\
Boy & $40(56)$ \\
Girl & $32(44)$ \\
Age (month) & \\
$36-48$ & $44(61)$ \\
$49-60$ & $28(39)$ \\
\hline Note: univariate analysis &
\end{tabular}

Table 2 Normality and Data Homogeneity Tests

\begin{tabular}{lc}
\hline Type of Test & p Value \\
\hline Normality test & \\
Measurement tape & 0.093 \\
Noviemeter & \\
Homogeneity test & \\
Measurement tape & 0.460 \\
Noviemeter & \\
\hline
\end{tabular}

Note: "Kolmogorov-Smirnov test (sample >50) and Levene test, $\mathrm{p}<0.05$ significant 
Table 3 Differences of Measurement Results between Measurement Tape and Noviemeter

\begin{tabular}{lccc}
\hline Head Circumference Device & Mean & Mean Difference & p Value \\
\hline Measurement tape & 49.250 & 0.05 & \multirow{2}{*}{0.257} \\
Noviemeter & 49.300 & & \\
\hline
\end{tabular}

Note: *dependent t test, $\mathrm{p}<0.05$ significant

Table 4 Diagnostic Test of Noviemeter in Under-Five Child Head Circumference Measurement

\begin{tabular}{lccc}
\hline Examination & AUC $^{*}$ (\%) & Sensitivity $^{*}$ (\%) & Specificity $^{*}$ (\%) \\
\hline Head circumference & 91.8 & 87.0 & 88.4 \\
\hline Note: ${ }^{*}$ receiver operating curve test &
\end{tabular}

Note: *receiver operating curve test

were also proven to have a similar variance (homogenous) with a p value of 0.460 , showing that the data from the two measurement devices were comparable.

The results of the dependent $t$ test on the head circumference measures using the Noviemeter and the measuring tape demonstrated a difference of $0.05(\mathrm{p}=0.257)$, showing an insignificant difference (Table 3 ).

Based on the receiver operating curve result, the AUC value for the head circumference measurement using the Noviemeter was $91.8 \%$, which was a very strong AUC value (Table 4).

\section{Discussion}

The majority of the under-five children in this study were boys (56\%) and 36-48 months old (61\%). The small sample size of this study is because this study was performed during the COVID-19 pandemic. In addition, the lack of parental knowledge and awareness on the importance of the early detection of brain development and growth in under-five children through head circumference measurement is also a factor that hinders participation in this study, even though the research team visited them in their own house.

Several studies have demonstrated that environmental and genetic factors influence the development of children. The environmental factors include the knowledge of the mother regarding under-five child development. Parental involvement in monitoring child development is crucial for good child growth and development. ${ }^{16-18}$

Under-five mothers, cadres, health care workers, and the community must understand the importance of growth and development monitoring. It is necessary to ensure that the parents have the appropriate knowledge and awareness regarding brain development monitoring through routine and guided monitoring to ensure the child's optimum growth. ${ }^{19,20}$

In this study, most subjects had mothers with a good educational background of a minimum of senior high school. According to BakerHenningham and Lopez Boo, ${ }^{21}$ parents with higher education and experience will better apply what they know. For example, they will understand the importance of a child's growth and development monitoring and use it for their child.

Based on the results of the statistical tests, a difference of $0.05(\mathrm{p}=0.257)$ in the measurement results between the two measuring instruments was observed, indicating that there is no difference in head circumference measurement results between using a measuring tape and a noviemeter. No significant difference was observed in the two measurements performed consecutively, although two operators did the measurement. This result supports Thezar et al., ${ }^{22}$ stating that measuring head circumference using measurement tape will give good measurement results if the child is cooperative. However, not all children are cooperative, and head circumference measurement using measurement tape in these 
children may result in inaccurate results as the child may move their head a lot during the measurement. In this situation, noviemeter is assumed to be an alternative digitalized solution to measure the head circumference to accurately estimate the brain growth inside the child's head. ${ }^{12}$

In Indonesia, the Ministry of Health has issued the Decree of Minister of Health Number 25 of 2014 on Child Health and the Decree of Minister of Health Number 66 of 2014 on Child Growth and Development Monitoring that stated the requirement for routine head circumference measurement in under-five children. ${ }^{23}$ Currently, the measurement tape is the gold standard for measuring head circumference. ${ }^{24,25}$ The tape is considered to have several advantages, such as being easy to carry, no need for batteries, and no need for calibration. However, there is also a limitationin using thetapeas itneeds collaboration from the child. Noviemeter is a digitalized device designed to measure the head circumference in under-five children without touching the child's head, thus reducing the tension that the child feels during measurement. Therefore, it is a tremendous advantage for measuring head circumference in children who refuse to cooperate with the operator. The principle of noviemeter is similar to the measurement tape, that is measuring head circumference from the glabellar or supraorbital bone to the occipital bone. The noviemeter uses four distance sensors using infrared that works on detecting an object to get the figure of the object and its distance by making use of the heat radiated from the object. ${ }^{26,27}$ Noviemeter can be used in health clinics, private practices, public health centers, and integrated health posts as it is easy to use and easy to read, making interpretation easier as it provides easily interpreted data based on the comparison with the appropriate head circumference classification based on age and gender, so the operator does not have to make the comparison manually. Another advantage is that the result can also be printed, making the job of the operator easier.

\section{Conclusions}

Noviemeter has high accuracy in both sensitivity and specificity for measuring head circumference. The result of head circumference measurement using Noviemeter is not significantly different from that of the measurement tape. Still, it is a better tool to measure head circumference in uncooperative children.

\section{Conflict of Interest}

All authors stated that there was no conflict of interest in this study.

\section{References}

1. Prawirohardjo S. Ilmu kebidanan. $4^{\text {th }}$ Edition. $5^{\text {th }}$ printing. Jakarta: PT Bina Pustaka Sarwono Prawirohardjo; 2016.

2. Soetjiningsih, Ranuh G. Tumbuh kembang anak. ${ }^{\text {nd }}$ Edition. Jakarta: EGC; 2014.

3. Harris SR. Measuring head circumference: update on infant microcephaly. Can Fam Physician. 2015;61(8):680-4.

4. Nurhidayah I, Mediani HS, Hendrawati S. Tingkat perkembangan balita usia 1 bulan- 6 tahun di Kecamatan Cibiuk Kabupaten Garut. J Keperawatan Komprehensif. 2018;4(1):4757.

5. Kementerian Kesehatan Republik Indonesia. Profil kesehatan Indonesia tahun 2013. Jakarta: Kementerian Kesehatan Republik Indonesia; 2014.

6. Sulistyawati A. Deteksi tumbuh kembang anak. Jakarta: Salemba Medika; 2015.

7. Susanty A, Fadlyana E, Nataprawira HM. Manfaat intervensi dini anak usia 6-12 bulan dengan kecurigaan penyimpangan perkembangan. MKB. 2014;46(2):63-7.

8. Fadlyana E, Alishjahbana A, Nelwan I, Noor M, Selly, Sofiatin Y. Pola keterlambatan perkembangan balita di daerah pedesaan dan perkotaan Bandung, serta faktor-faktor yang mempengaruhinya. Sari Pediatri. 2013;4(4): 168-75.

9. Ribek N, Labir IK, Dewi IDAPC. Lingkar kepala dengan masa perkembangan pada bayi usia $0-12$ bulan. J Gema Keperawatan. 2013;6(1):72-6.

10. Yuniarti S. Asuhan tumbuh kembang neonatus bayi-balita dan anak pra-sekolah. Bandung: Refika Aditama; 2015.

11. Rahayu S. Pertumbuhan dan perkembangan balita di posyandu Surakarta. Interest J Ilmu Kesehat. 2014;3(1):88-92.

12. Ifflaender S, Rüdiger M, Koch $\mathrm{A}$, Burkhardt W. Three-dimensional digital capture of head size in neonates - a method evaluation. PLoS One. 2013;8(4):e61274. 
13. Dahlan MS. Penelitian diagnostik: dasardasar teoritis dan aplikasi dengan program SPSS dan Stata. Jakarta: Salemba Medika; 2009.

14. Smith JL, Sturrock HJ, Olives C, Solomon AW, Brooker SJ. Comparing the performance of cluster random sampling and integrated threshold mapping for targeting trachoma control, using computer simulation. PLoS Negl Trop Dis. 2013;7(8):e2389.

15. Sastroasmoro S, Ismael S. Dasar-dasar metodologi penelitian klinis. $5^{\text {th }}$ Edition. Jakarta: Sagung Seto; 2018.

16. Horwitz BN, Neiderhiser JM. Geneenvironment interplay, family relationships, and child adjustment. J Marriage Fam. 2011;73(4):804-16.

17. Mullineaux PY, DiLalla LF. Genetic influences on peer and family relationships across adolescent development: introduction to the special issue. $\mathrm{J}$ Youth Adolesc. 2015;44(7):1347-59.

18. Shabariah R, Farsida, Parameswari I. Hubungan ukuran lingkar kepala dengan perkembangan anak usia 12-36 bulan berdasarkan Skala Denver Development Screening Test-II (DDST-II) di Posyandu RW o3 Mustika Jaya Bekasi Timur November 2016. J Kedokt Kesehat. 2019;15(1):46-55.

19. Sutiani R, Lubis Z, Siagian A. Gambaran pengetahuan dan keterampilan kader posyandu dalam pemantauan pertumbuhan bayi dan balita di wilayah kerja Puskesmas Desa Lalang tahun 2014. Gizi Kesehat Reproduksi Epidemiologi. 2014;1(3):1-8.

20. Tengkawan J, Anandhika A, John RE, Ihyauddin Z, Jessica K, Karuniawaty TP. Adv Soc Sci Educ Humanit Res. 2020;454:14650 .

21. Baker-Henningham H, Lopez Boo F. IZA
DP No. 5282: Early childhood stimulation interventions in developing countries: a comprehensive literature review [Internet]. Bonn: IZA Institute of Labour Economics; 2010 [cited 2020 June 15]. Available from: http://ftp.iza.org/dp5282.pdf.

22. Thezar D, Masloman N, Mandei JM. Hubungan lingkar kepala dan perkembangan bayi di Poli Bayi dan Tumbuh Kembang RSUP Prof. DR. R. D. Kandou. e-CliniC. 2016;4(1):1-6.

23. Peraturan Menteri Kesehatan Republik Indonesia Nomor 66 Tahun 2014 tentang Pemantauan Pertumbuhan, Perkembangan, dan Gangguan Tumbuh Kembang Anak.

24. Casadei K, Kiel J. Anthropometric measurement. Treasure Island: StatPearls Publishing; 2021.

25. Yepes-Calderon F, Han JE, Nelson MD, J. McComb JG. Automatic head's circumference estimator: a tool running on clinical networks. In: Zhang J, Chen PH, editors. Proceedings of SPIE 10579, Medical Imaging 2018: imaging informatics for healthcare, research, and applications; 2018 February 13-15; Houston, Texas, United States. Bellingham: Society of Photo-Optical Instrumentation Engineers; 2018. p. 105791M.

26. Priyulida F, Rianto Y. Penggunaan alat terapi stimulator integrasi dengan infra red berbasis simulasi. J Mutiara Elektromedik. 2017;1(1):1-6.

27. Putra IWGAE, Sutarga IM, Kardiwinata MP, Suariyani NLP, Septarini NW, Subrata IM. Modul penelitian uji diagnostik dan skrining [Internet]. Denpasar: Universitas Udayana; 2016 [cited 2020 July 12]. Available from: https://simdos.unud. ac.id/uploads/file_pendidikan_1_dir/ d204d4a5ado870a0965416e671a38791.pdf. 